\title{
Trading Arrangements and Industrial Development ${ }^{*}$
}

\author{
Diego Puga \\ CEP, London School of Economics; \\ and CEPR \\ Anthony J. Venables \\ London School of Economics; \\ and CEPR \\ CENTRE for ECONOMIC PERFORMANCE \\ Discussion Paper No. 319, December 1996
}

\begin{abstract}
This paper outlines a new approach for analysing the role of trade in promoting industrial development. It offers an explanation as to why firms are reluctant to move to economies with lower labour costs, and shows how trade liberalisation can change the incentives for firms to locate in developing countries. Unilaterally liberalising imports of manufactures can promote industrialisation, but membership of a preferential trading arrangement is likely to create larger gains. South-South PTAs will be sensitive to the market size of member states, while North-South PTAs seem to offer better prospects - for participating Southern economies, if not for excluded countries.
\end{abstract}

* Thanks to Maurice Schiff, Alan Winters and referees for valuable comments on an earlier version. This paper was prepared for the Research Project on Regional Integration of the International Trade Division of the World Bank. The views expressed here are those of the authors and do not necessarily reflect those of the World Bank or its affiliated organizations.

KEY WORDS: preferential arrangements, industrialisation, development, linkages. JEL CLASSIFICATION: F12, R12.

Addresses:

Diego Puga

Centre for Economic Performance

London School of Economics Houghton Street

London WC2A 2AE, UK

Email: d.puga@1se.ac.uk
Anthony J. Venables

Department of Economics

London School of Economics

Houghton Street

London WC2A 2AE, UK

Email: aj.venables@lse.ac.uk 


\section{Introduction}

How do different trading arrangements influence the industrialisation process of developing countries? Can preferential trading arrangements (PTAs) be superior to multilateral liberalisation, or at least an alternative when multilateral liberalisation proceeds slowly? If so, what form should the PTAs take? Are developing countries better advised to seek PTAs with developed countries or amongst themselves?

Traditional analysis of these issues has been based on the ideas of trade creation and trade diversion. For example, consider a pair of less developed countries (LDCs) whose comparative advantage is such that each produces agricultural products and a different manufactured good, and exports only agriculture, importing manufactures from a developed country. Can a PTA between the LDCs promote industrialisation? The answer is yes - they will trade their manufactures instead of importing them from the developed country. This will lead to increased production of manufactures, but the basis of this is trade diversion. As such it may be welfare reducing - essentially the PTA and consequent trade diversion act as a way of creating regional import substitution (for a survey and discussion of these issues see de Melo, Panagariya and Rodrik, 1993).

The problem with this analysis is that it starts from assuming a pattern of comparative advantage. The initial situation is one in which the LDCs import manufactures only because the developed country is assumed to have a comparative advantage in manufactures, and given this assumption, the conclusion that PTAs promote industrialisation in the LDCs by working against their comparative advantage is hardly surprising. The assumption certainly stands in sharp contrast to the apparently changing comparative advantage of newly industrialised countries. The experience of these countries suggests the need for an analysis in which the pattern of comparative advantage is not set in stone but is potentially flexible, and in which LDCs can develop and converge - in both income and economic structure - to developed economies.

How can the analysis be extended to allow for the dramatic changes in relative income and in industrial structure that we have seen in some developing countries? One way is to build a model of trade and growth, and then see how trading arrangements change the incentives for factor accumulation, and hence countries' rates of growth and 
relative factor endowments. While there is a small literature on the growth effects of PTAs (see Baldwin and Venables, 1995, for a survey), papers in this area do not yet have sufficient micro-foundations to be able to convincingly discriminate between different types of trading arrangement.

An alternative approach is to suppose that there are few fundamental differences between countries which generate immutable patterns of comparative advantage, and instead the pattern of trade and development we see in the world economy is determined mainly by history. Cumulative causation has created concentrations of industrial activity in particular locations (developed countries) and left other areas more dependent on primary activities. According to this approach economic development can be thought of as the spread of these concentrations from country to country, and it is possible that different trading arrangements may have a major impact on this development process. By changing the attractiveness of countries as a base for manufacturing production they can potentially trigger - or postpone - industrial development.

In this paper we develop this approach, and illustrate how trading arrangements can shape economic development. The building blocks for our approach are familiar from new trade theory, and from somewhat older development economics. As in new trade theory, we focus on the location of firms with increasing returns technologies operating in imperfectly competitive environments. From development economics we take the ideas of forward and backward linkages between firms. Combining these linkages with imperfect competition creates pecuniary externalities between firms, and it is this that provides the mechanism for cumulative causation. The pecuniary externalities support existing agglomerations of industrial activity, and also provide a mechanism for the 'take-off' of newly industrialising economies.

Throughout the paper we shall concentrate exclusively on the trade flows generated by these agglomeration forces, and assume that countries have no underlying differences in technology or relative factor endowments. This is clearly an extreme position, and one which abstracts from traditional comparative advantage. By abstracting from such differences we do not mean to suggest that they are unimportant. 
Rather, we seek to focus on the way in which agglomeration forces can determine industrial location, and on how this may be changed by trade policy.

The paper is organised as follows. In the next section we provide an overview of the analytical framework that we shall use throughout the paper, and which is presented in more detail in the appendix. In section 3 we run through a series of experiments, simulating the effects of different trading arrangements on the industrialisation process, and showing how alternative arrangements can lead to quite different patterns of development. It turns out that trade liberalisation may have dissimilar impacts on similar member economies, creating internal tensions within a PTA. In section 4 we draw out the policy implications of our findings, discussing some evidence of the empirical relevance of the forces captured by this framework, and relating our results to the recent experiences of different LDCs. A final section summarises the main conclusions.

\section{An analytical framework}

Details of our model are given in the appendix, and here we only give an informal overview of its key features.

We shall assume that each country has - or may have - two sectors. One is a perfectly competitive commodity sector which, in line with most of the literature, we shall call agriculture. It produces output using a sector specific factor (land) and a sectorally mobile factor (labour). For simplicity we assume that this product is freely traded..$^{[1]}$ We focus the analysis on the other sector, industry, although the two sectors interact in general equilibrium. As industry relocates, so agriculture adjusts to release or absorb labour and to maintain payments balance; land use in agriculture means that the wage in a country will be higher the smaller is that country's agricultural employment.

\footnotetext{
1 A more realistic modelling of the agricultural sector including trade costs would not alter the main results of the paper but would shift the focus away from our main concern here, the effects of trade policy on industrialisation. The effects of agricultural trade costs in a model of this type are explored in Fujita, Krugman and Venables (1997). We also assume that agriculture does not use intermediates Pande (1997) relaxes this assumption.
} 
The industrial sector takes the form of a monopolistically competitive industry in which firms produce differentiated products. This is modelled as 'Dixit-Stiglitz' monopolistic competition, in the form applied to international economics by Helpman and Krugman (1985) and others. We generalise this model to include intermediate goods, along the lines of Krugman and Venables (1995) and Puga and Venables (1996, forthcoming). That is, each firm's output is used both as a final good and as an intermediate good, and each firm uses as inputs both labour and the output of other firms. The presence of intermediate goods, when combined with imperfect competition, generates the forward and backward linkages which are central to our approach. Rather than working with a full input-output structure (as in Puga and Venables, 1996) we work with a single aggregate sector that uses its own output as input. Corresponding to our assumption that there is a single manufacturing sector, there is also a single trade policy instrument - tariffs on imports of these manufactured goods.

Firms enter and exit in response to short-run profit opportunities, giving a long-run zero profit equilibrium. It is this that determines the level of industrial activity in each country and to understand it, it is helpful to think of there being four forces determining the short-run profitability of firms in a particular country. The first is factor market competition. A country that has a lot of industry will have higher wages, this reducing firms' profitability. The second is product market competition. Given some trade barriers a country with more industry will, other things being equal, have lower output prices, this also reducing profitability. These are standard 'neoclassical' forces, working for the dispersion of activity - encouraging firms to locate where labour is cheap and where there is little supply from other firms.

Working in the other direction are cost (forward) and demand (backward) linkages. Cost linkages occur because having more firms in a location means that more intermediate inputs are locally available, this reducing costs and raising short run profits. Demand linkages arise as having more firms in a location increases intermediate demands, this raising the sales and profitability of other firms. Both these forces mean that firms want to set up in the same country as existing firms - they are therefore 'centripetal' forces, working towards the concentration of industry in a single location. 
It is tension between these four forces that determines the equilibrium pattern of location. If the first two are more powerful than the last two then it will generally be the case that industry operates in all locations and we are then in a standard 'new trade theory' world. In this case the model does not generate a distinction between developed and less developed countries - if we assume that countries all have the same relative endowments, technologies, and preferences, then they will all have similar industrial structures and patterns of trade. ${ }^{[2]}$ But if the last two forces are powerful enough compared to the first two, then equilibrium will involve agglomeration of manufacturing in a subset of countries. Under these circumstances the presence of an extra firm will raise the short run profitability of existing firms in the country, and since firms enter in response to short run profits, this will attract further firms, so generating a cumulative process of industrial agglomeration.

In this case equilibrium will not be unique - there is nothing in the model to determine in which country or countries the industrial agglomeration is located. However, equilibria have the property that - without assuming differences in underlying comparative advantage - the world will nevertheless be organised into some countries with industry, and other countries without. Real income differences are associated with this uneven pattern of industrialisation. The countries with industry will be richer for two reasons: the demand for labour in industry raises wages, and the local supply of manufactures reduces the consumer price index. They will also have a larger market, arising both from consumer and intermediate demands. And they will have a better supply of intermediate goods, showing up as a lower price index for these goods. At this equilibrium there may be quite large differences in wages and unit labour costs between the developed and less developed countries, but despite this it is not profitable for a firm to relocate to an LDC. If a firm were to do so it would benefit from lower wages, and from being the only local supplier in this market (our factor market and product market competition effects). But it would forego the benefits of

2 Although there may be net trade arising from market size differences alone, see for example Krugman (1980). 
proximity to its suppliers and its industrial customers (the forward and backward linkages).

How does trade liberalisation affect this? In this model whether agglomeration occurs or not depends critically on the level of trade barriers. With extremely high barriers (autarky) there cannot be agglomeration - each country must have industry to supply its consumers. And under perfectly free trade there cannot be agglomeration either - proximity to industrial suppliers and consumers has no economic significance if there is no cost to trading across space. Agglomeration is therefore only a possibility at levels of trade barriers between these extremes, and changing trade barriers may cause agglomerations to develop and to disappear. ${ }^{[3]}$

In this paper we shall explore a variety of trade liberalization experiments, and see three main mechanisms at work. First, if the barriers incurred in exporting from an LDC are reduced, then this reduces one of the disadvantages of being in an LDC; it will now be cheaper to export from the LDC to the large developed country market. This means that we expect to see reductions in developed country import barriers facilitating the spread of industry to LDCs. What about LDC import barriers? There are two mechanisms here, pulling in opposite directions. First, opening markets to increased product market competition from foreign firms reduces the potential profitability of local firms. But second, lower import barriers mean that intermediate goods can be imported more cheaply, and this will raise potential profitability. Combining these mechanisms we shall often see an effect which is, in some sense, greater than the sum of the parts. Cumulative causation can be triggered, leading to quite large changes in levels of industrial activity. ${ }^{[4]}$

Different PTAs offer a variety of combinations of reductions in trade barriers, which affect differently countries with different amounts of established industry, different wage rates, and markets of different sizes. In the next section we look at how the balance between market access, import competition, wage differentials, and linkages

3 See Krugman and Venables (1995) and Puga (1996) for development of this point.

${ }^{4}$ We do not allow trade liberalisation to change the technology in use, or to change the price markups through strategic interaction between firms. As a consequence equilibrium firm scale is constant. 
is affected by different PTAs. We study whether trade policy can make industry spread to LDCs, and if so what trading arrangements are most conducive to this spread.

\section{Trading arrangements}

In this section we go fairly rapidly through a set of trade policy experiments, and postpone a fuller discussion of policy issues until section 4 . In all our experiments we shall work with four countries, assumed to be of equal size (i.e. having the same factor endowments). We assume values for parameters such that there is an initial equilibrium in which manufacturing is concentrated in just two of the countries. Within the formal structure of the model which two countries is indeterminate. We simply label the two countries that have industry North, and the two that do not, South. ${ }^{[5]}$

We set the following structure of trade barriers between economies. All trade flows in manufactures have an equal level of real trade costs per unit, which can be thought of as the costs incurred when doing business at a distance. In addition, there are ad valorem tariffs. In the initial equilibrium we assume that these are zero between the two Northern economies, and positive and equal on all other manufactured trade flows. The experiments we report in this section are reductions in some or all of the tariff barriers, corresponding to different trade liberalisation packages. ${ }^{[6]}$ In all the experiments we undertake we assume that the two Northern economies follow identical policies, and keep identical economic structures (the reason for this is simply to focus on South). We shall consequently refer to North as a single policy maker.

We shall illustrate outcomes by presenting a series of figures with the level of tariffs, denoted $T$, on the horizontal axis ( $T=1$ is free trade, $T-1$ the ad valorem tariff rate).

\footnotetext{
${ }^{5}$ We choose four countries because for the questions we want to address we need two Southern economies, and there are some benefits from having a structure which allows for symmetry between regions. In the general case of a large number of different size economies, while it is generally the case that industry will only operate in a subset of countries, there are many possible equilibrium assignments of industry to countries.

${ }^{6}$ The distinction between real trade costs and tariffs is that only the latter generate revenue. Changes in either type of barrier have similar effects on the location of industry.
} 
The initial value, $\bar{T}$, is the same for all manufacturing trade flows involving a Southern economy, and liberalisation will reduce some (or, in the case of multilateral liberalisation, all) of these tariffs, with those not affected by the liberalisation held at $\bar{T}$. The figures are constructed by reducing tariffs from their initial level in a series of small steps. At each step there is a change in the short run profitability of firms, and we let our entry and exit dynamic work until a new long run equilibrium is established. The tariff is then reduced by the next step, and the procedure repeated. The figures therefore trace out values of variables along a stable equilibrium path from the initial equilibrium, and we shall describe the evolution of the economy along this path. ${ }^{[7]}$

In each sub-section below two figures are presented. The vertical axis in the $a$ figure is the share of world industry in each of the two Southern economies (the Northern share obviously given by one minus the sum of Southern shares), and we shall use these figures to demonstrate the way in which liberalisation causes industry to relocate. The $b$ figures give real wages inclusive of tariff revenue (distributed to workers in a lump sum manner) for the two Southern countries and for North. These change because of changes in demand for labour, because of changes in the consumer price indices in each country, and because of changes in levels of tariff revenue. ${ }^{[8]}$

All the results presented are based on numerical simulation of the model, and the parameter values underlying the simulations are given and discussed in the appendix. We do not report a systematic sensitivity analysis in the paper, but do comment at a number of points on how changing parameters of the model affects results. From the research we have undertaken we think that the qualitative conclusions we present are quite robust.

\footnotetext{
${ }^{7}$ This procedure is necessary because, in general, the model exhibits path dependence.

${ }^{8}$ The evolution of real wages exclusive of tariff revenue is not dissimilar from that presented in the figures.
} 


\subsection{Multilateral liberalisation}

We take as benchmark case multilateral trade liberalisation between all countries. Figure $1 a$ shows that with initial tariff barriers, $\bar{T}=1.15$ (for all North-South and SouthSouth trade, while there is free North-North trade), the whole of industry is agglomerated in North - the lines $S_{1}$ and $S_{2}$ giving the share of each of the Southern economies are at zero. At this equilibrium Southern real wages are approximately $65 \%$ of Northern (despite the fact that there are no differences in technology, labour skills or relative endowments). As global tariffs $T$ are reduced there comes a point, (around 1.14), at which it becomes profitable for some firms to relocate South. We have already outlined the forces driving this; short run profitability of Southern firms (potential, if not yet actual firms) is reduced by having a more open market, but is increased by the fall in the price of imported intermediate goods and by easier access to the large Northern market. These last two forces - combined with the large initial wage difference - dominate, causing industry to move South ${ }^{[9]}$.

Notice however that industry initially only starts operating in one of the Southern countries. If the two Southern countries are identical, the choice of which is entirely a matter of chance - we shall label it $S_{1}$. The reason for this uneven spread is that the first firms to set up create cost and demand linkages to other firms in the same country. They also raise wages, but the linkage effects are stronger, so what we see is a second industrial agglomeration forming in just one of the LDCs. ${ }^{[10]}$

9 This is a general property. If trade barriers - real as well as tariff - are low enough, then agglomeration in a subset of economies is unsustainable and industry will operate in all countries, see Puga (1996). The agglomeration of industry in North will be sustainable over a wider range of tariffs if the Northern economies are larger (relative to South) or more integrated (lower intra-Northern trade barriers).

10 There is an equilibrium with industry operating in both $S_{1}$ and $S_{2}$ but it is unstable; if country 1 had slightly more firms than country 2 it would have higher short run profits, attracting more firms, and raising profits further. There may be other mechanisms which reinforce this result-most obviously a confidence factor created by early entrants' success. 


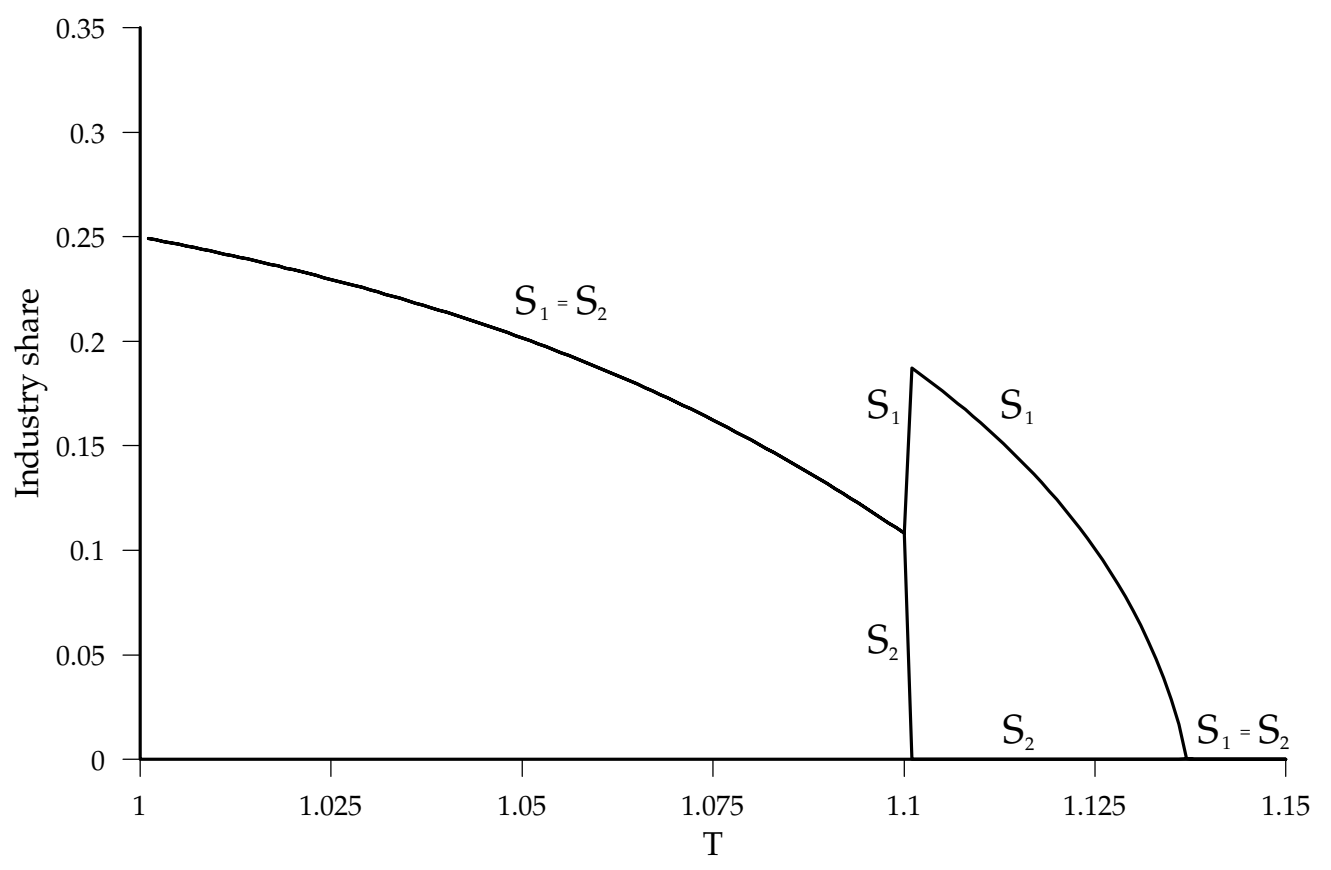

FIGURE 1a

Multilateral liberalisation: Share of industry in each country

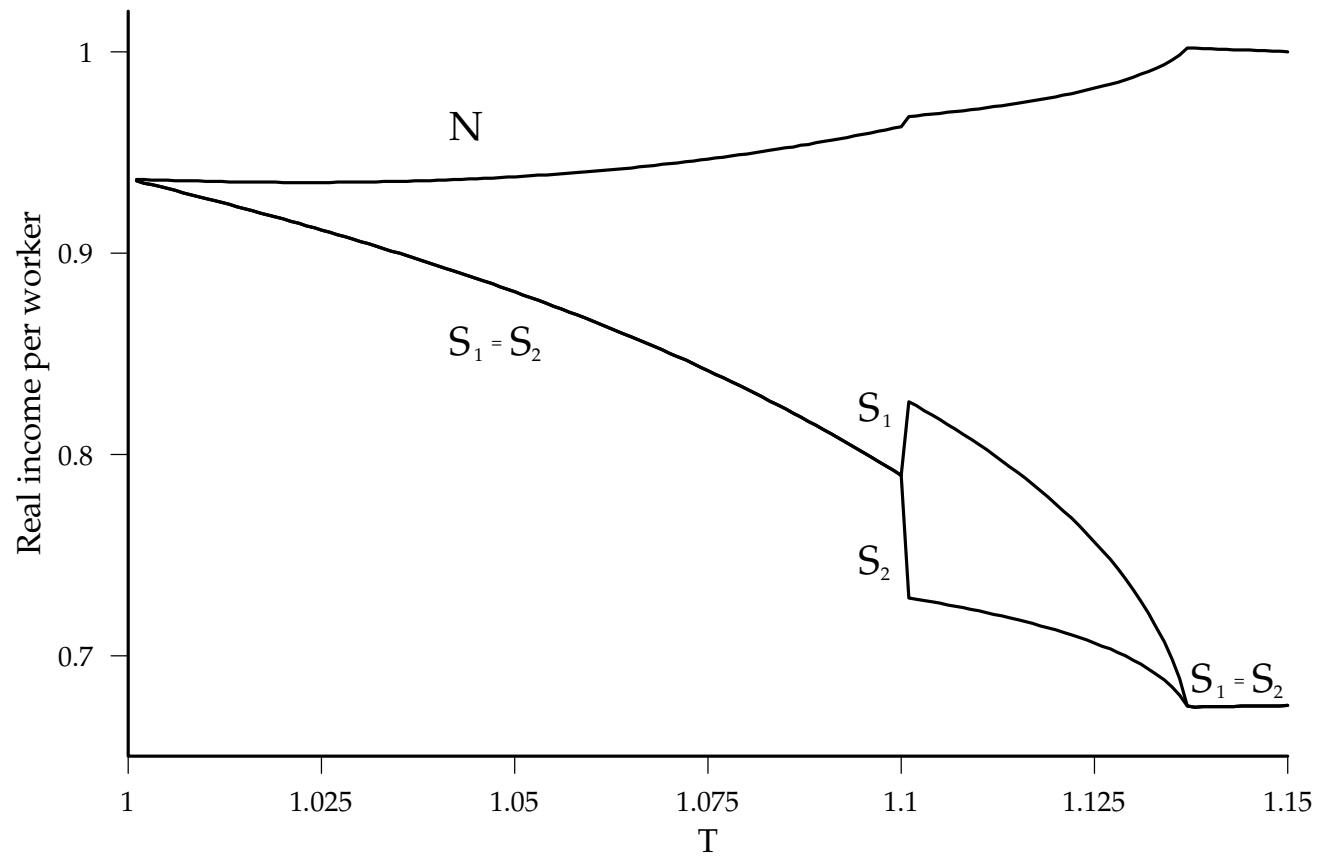

FIGURE 1b

Multilateral liberalisation: Real income per worker 
The range of tariffs from around 1.14 to 1.10 is therefore one in which industry has spread to one Southern country, but not the other. ${ }^{[11]}$ As tariffs are reduced below this point it becomes profitable for manufacturing firms to become established in the other LDC, $S_{2}$. We see that this process is very abrupt, and partly at the expense of $S_{1}$, which experiences a small fall in its share of world industry. At tariffs below this point the two Southern economies are identical, and further reductions in $T$ bring a steady relocation of industry to these economies. At completely free trade each of the now developed Southern countries has $25 \%$ of world industry (equal to its share of the world endowment).

The corresponding real wage picture is $1 b$. Although welfare effects are not directly caused by the evolution in country shares of industry they are closely related with it. Countries with more industry have higher labour demand and have to import fewer varieties subject to trade barriers, both effects supporting the real income differences in figure $1 b$. This comes through clearly in the increase in Southern economies' wages. Northern real wages decline, although this result is not general; the combined effect of changing labour demand and price indices on Northern wages is ambiguous, with the balance of decline and increase depending quite sensitively on parameter values.

There are two main messages from these figures. First, trade liberalisation breaks down existing agglomerations of activity. As trade costs are reduced firms become more footloose and more sensitive to international differences in factor prices, and it is this that drives the convergence in the figures. Second, the benefits will not necessarily be equally divided between the Southern economies. It follows directly from the presence of agglomeration forces in the model that as the Northern agglomeration starts to break down, so new agglomerations may develop.

${ }^{11}$ The extent and form of divergence between Southern economies depend on model specifications. If a full input-output structure is considered and not all sectors are tightly linked to each other, each Southern economy may get agglomerations of different sectors, although there is always a tendency for unequal development on the aggregate. 


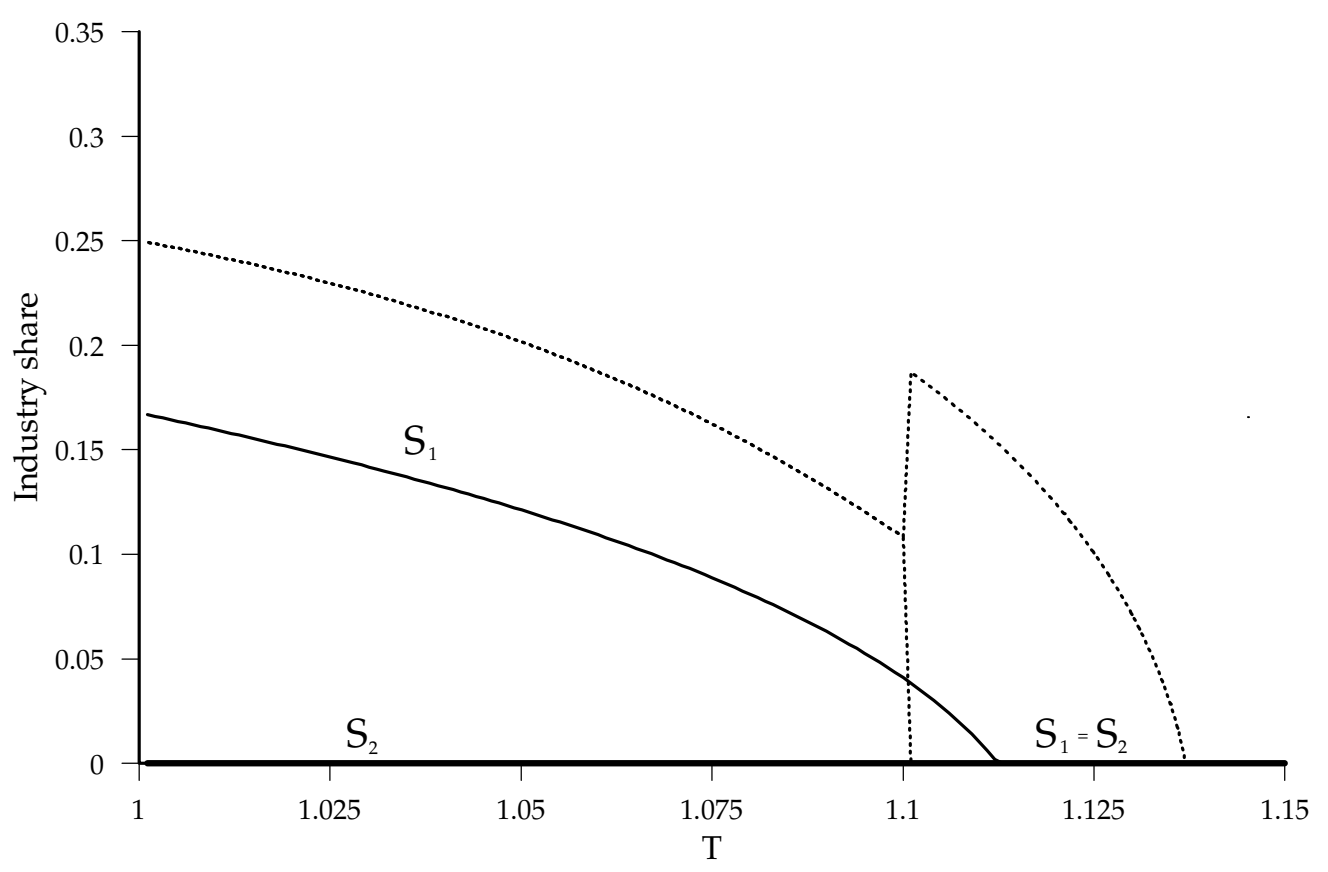

FIGURE 2a

Unilateral liberalisation: Share of industry in each country

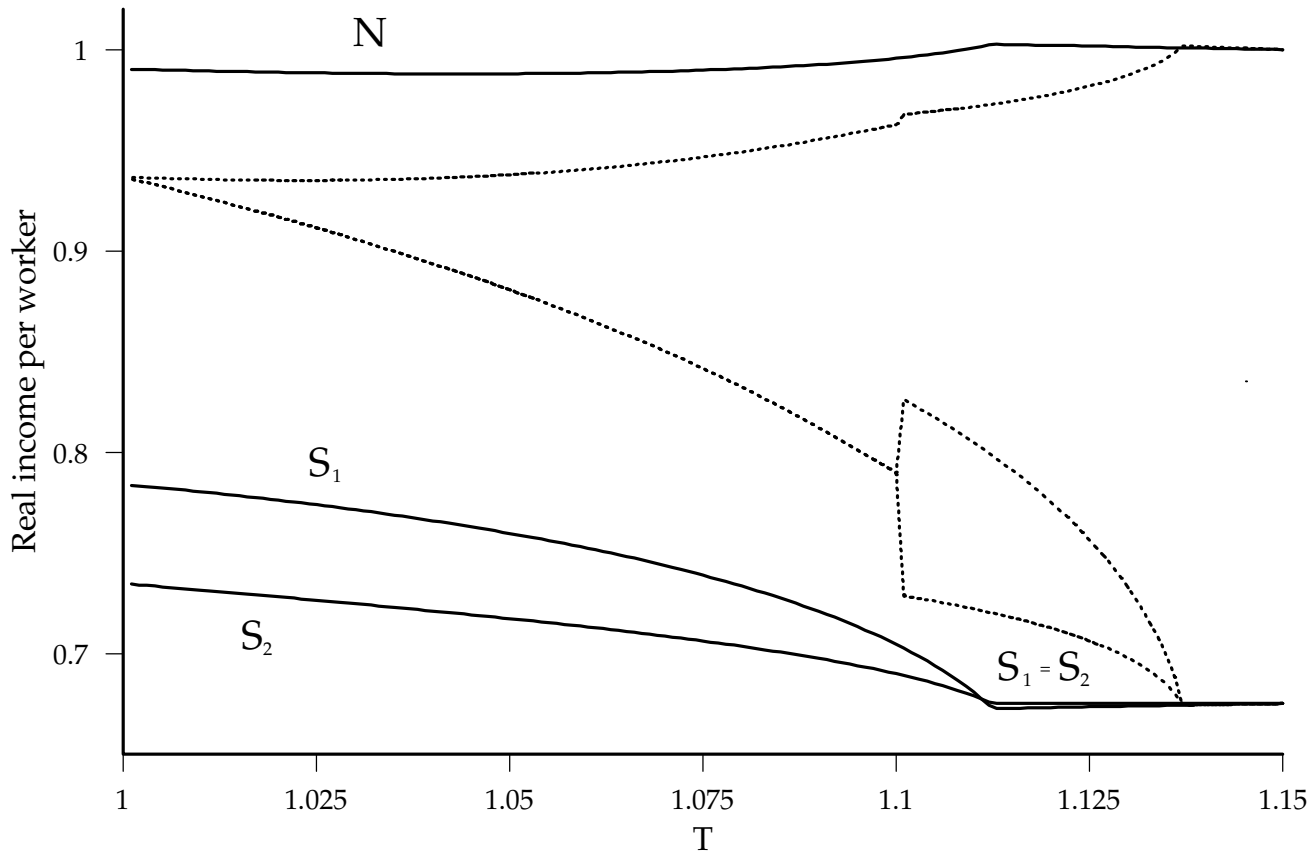

FIGURE $2 b$

Unilateral liberalisation: Real income per worker 


\subsection{Unilateral liberalisation.}

We now turn from multilateral to unilateral liberalisation. A single Southern economy $\left(S_{1}\right)$ engages in unilateral import tariff liberalisation, with all other barriers held constant (at value $\bar{T}=1.15$ ). The solid lines in figures $2 a$ and $2 b$ outline the process, with the dashed lines on this and all remaining figures giving multilateral liberalisation as a reference case.

The striking point to note about the figure is that openness to imports of manufactures causes manufacturing production to start. ${ }^{[12]}$ Import competition obviously has a negative effect through the product market, particularly since access to the Northern market is not liberalised. But the cheaper supply of imported intermediate goods becomes the dominant force, enabling industry to become established. This result is not general - for example, if the Southern economies were very small and faced high export barriers, unilateral liberalisation would not cause industry to develop. But providing this is not the case, we find that the combination of low wages and low cost intermediates (due to import liberalisation) are sufficient to lead to industrialisation. In cases we have studied industry will develop sooner and at larger scale (i.e., the $S_{1}$ curve will be higher) the greater is the share of intermediates in production, and the larger is the market in the liberalising economy.

Furthermore, the unilateral reduction unambiguously raises wages in the liberalising country. ${ }^{[13]}$ Although the policy has no direct effect on the other Southern economy (it has no industry to benefit from $S_{1}{ }^{\prime}$ s liberalisation) it does experience a slight real wage increase - a terms of trade improvement due to the increased world supply of manufactures.

Comparing unilateral with multilateral liberalization, the continuing barriers to LDCs' exports mean both that it takes a lower tariff rate to start industrialisation and that, once

12 For fuller development of this argument in a somewhat different model see Venables (1996).

13 Before industrialisation takes off there is a slight real wage decrease in the liberalising economy because of falling tariff revenue, but as soon as it starts to attract some industrial production real wages inclusive of tariff revenue rise unambiguously. 


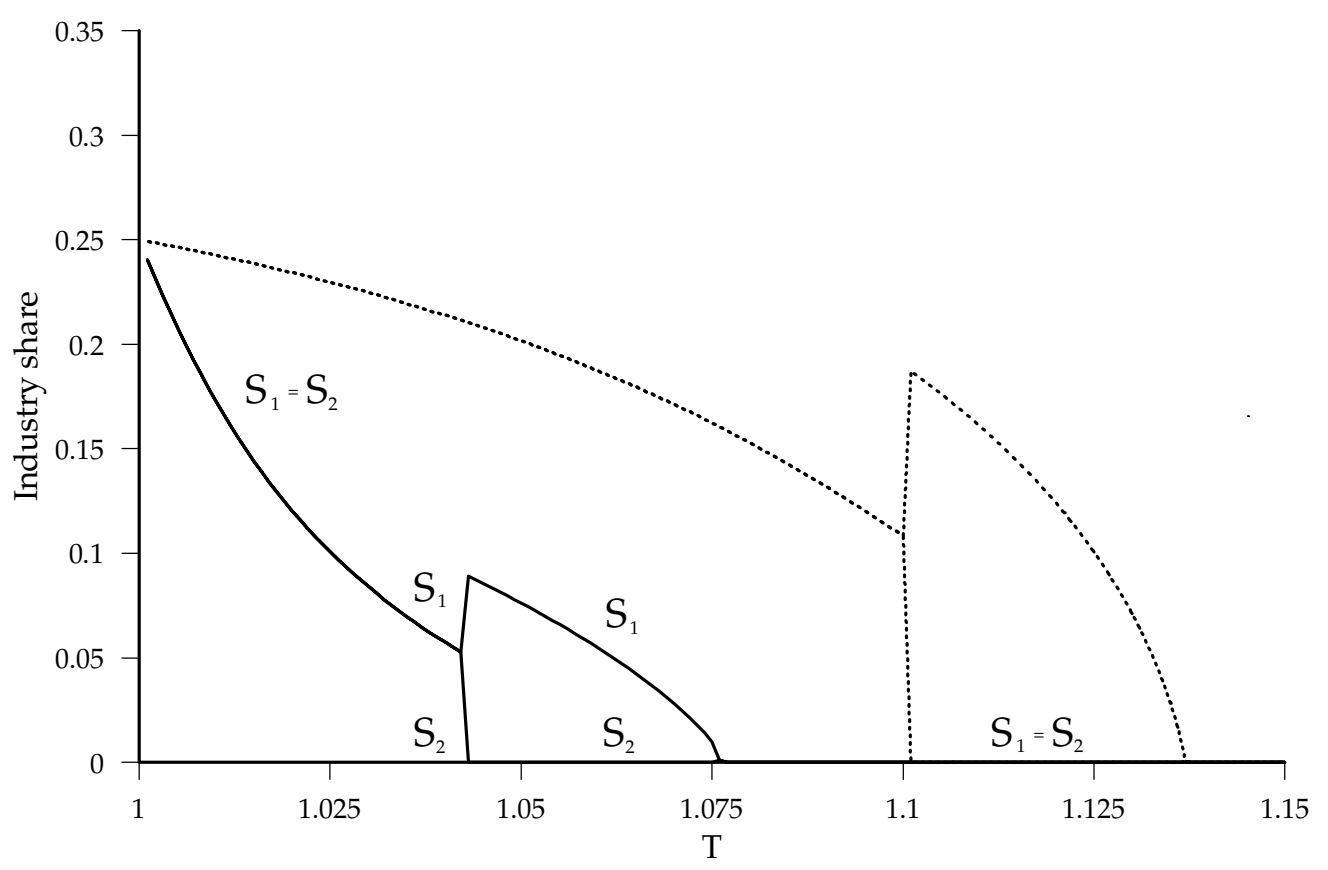

FIGURE 3a

South-South FTA: Share of industry in each country

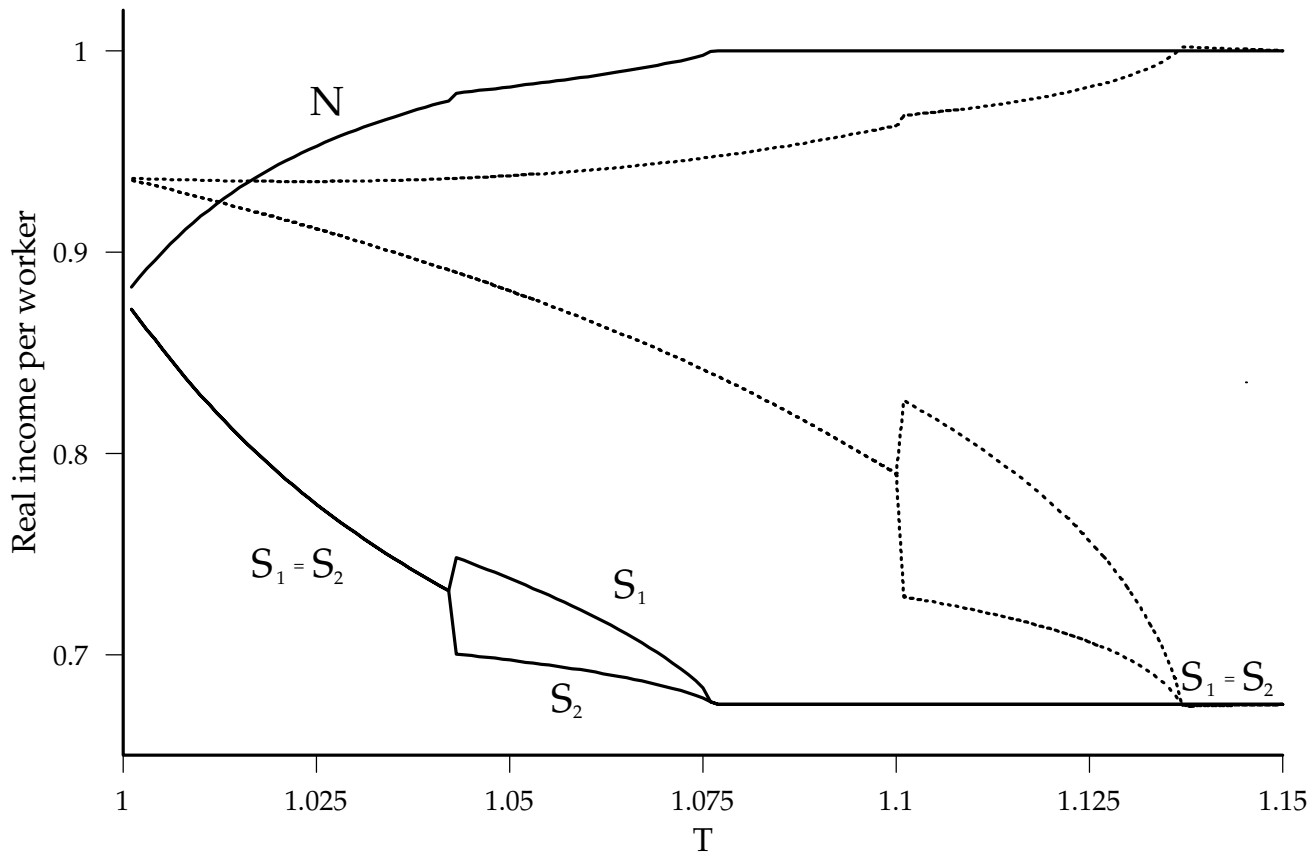

FIGURE 3b

South-South FTA: Real income per worker 
started, $S_{1}$ has a lower share of manufacturing than in the multilateral case. Associated with this, real wages are lower in $S_{1}$ than in the case of multilateral liberalisation.

\subsection{South-South PTA}

In a South-South PTA the two Southern economies reduce trade barriers between each other, with import barriers to and from North held constant. The results are illustrated in figures $3 a$ and $3 b$.

Once again, the trade liberalisation is sufficient to cause industry to become established in the LDCs, but the mechanism is completely different from the previous case of unilateral tariff reductions. In that case industry started in response to cheaper intermediate inputs - a force which cannot operate here as in the initial position no intermediates are affected by the tariff reduction. Instead, the driving force is the effective market enlargement caused by reducing intra-South barriers. Like the multilateral case, the spread of industry to LDCs is uneven, initially developing in one of the countries and only spreading to the second at lower trade barriers.

What can be said by way of comparison with the previous cases? Looking at industrial activity levels, both the Southern economies attract less industry than they do with multilateral liberalization, as they do not benefit from better access to Northern markets nor to Northern-produced intermediates. Compared to unilateral liberalisation we see that with the South-South arrangement industry is attracted later, although as tariffs become very small the gain is larger. Comparison of Southern real wage movements is similar.

Although the ranking of South-South PTA and multilateral liberalization is general, the ranking of South-South with unilateral is not. As we have pointed out, quite different mechanisms trigger industrialisation in the two cases. With a South-South PTA industrialisation is triggered by local demand, and will be earlier the higher is this demand. With unilateral liberalization it is triggered by forward linkages from imports, and its timing depends on the strength of these linkages. It is possible that if linkages are weak and Southern demand large then a South-South PTA may attract industry at a higher value of $T$ than does a unilateral liberalisation. 


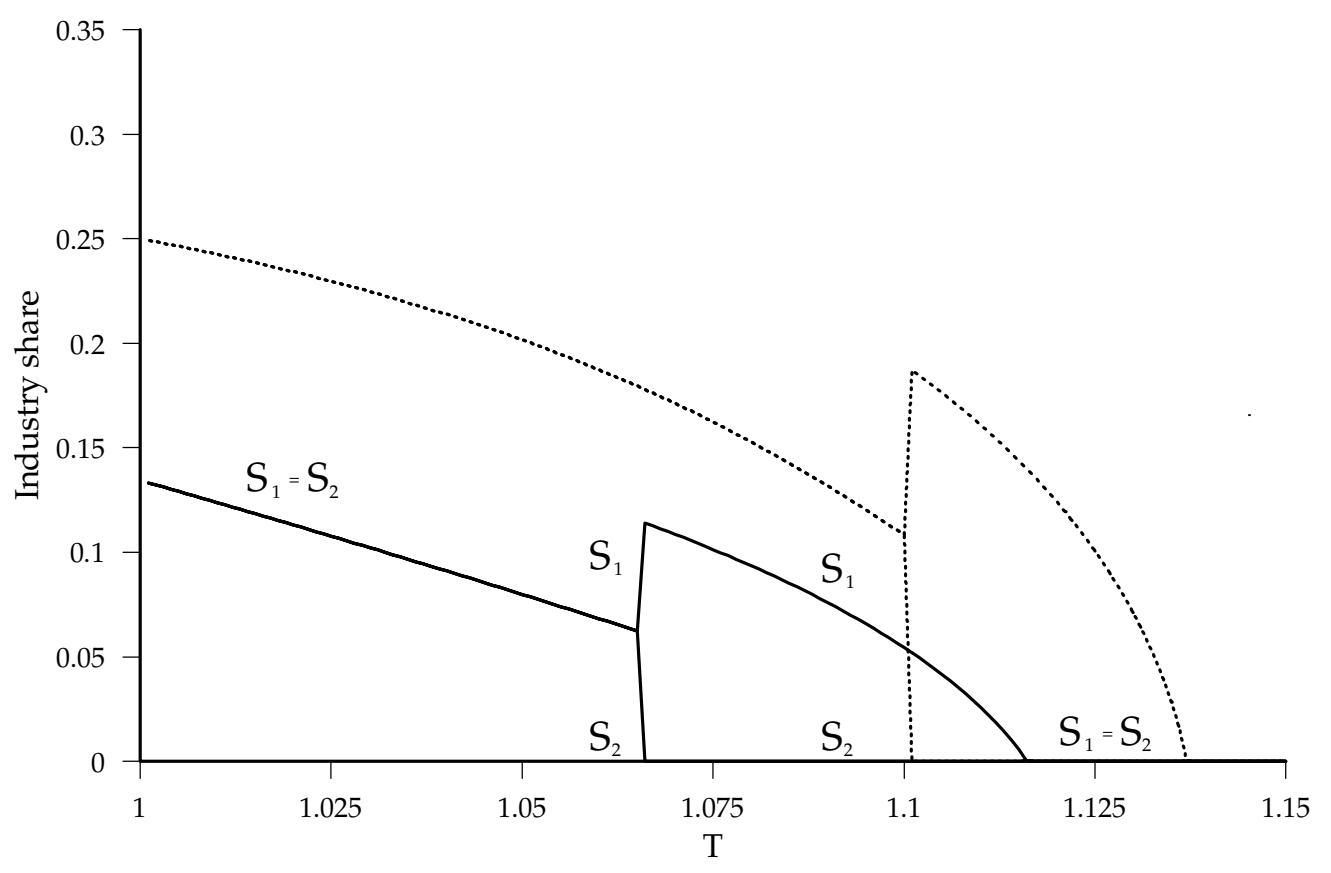

FIGURE 4a

Concerted MFN Southern liberalisation: Share of industry in each country

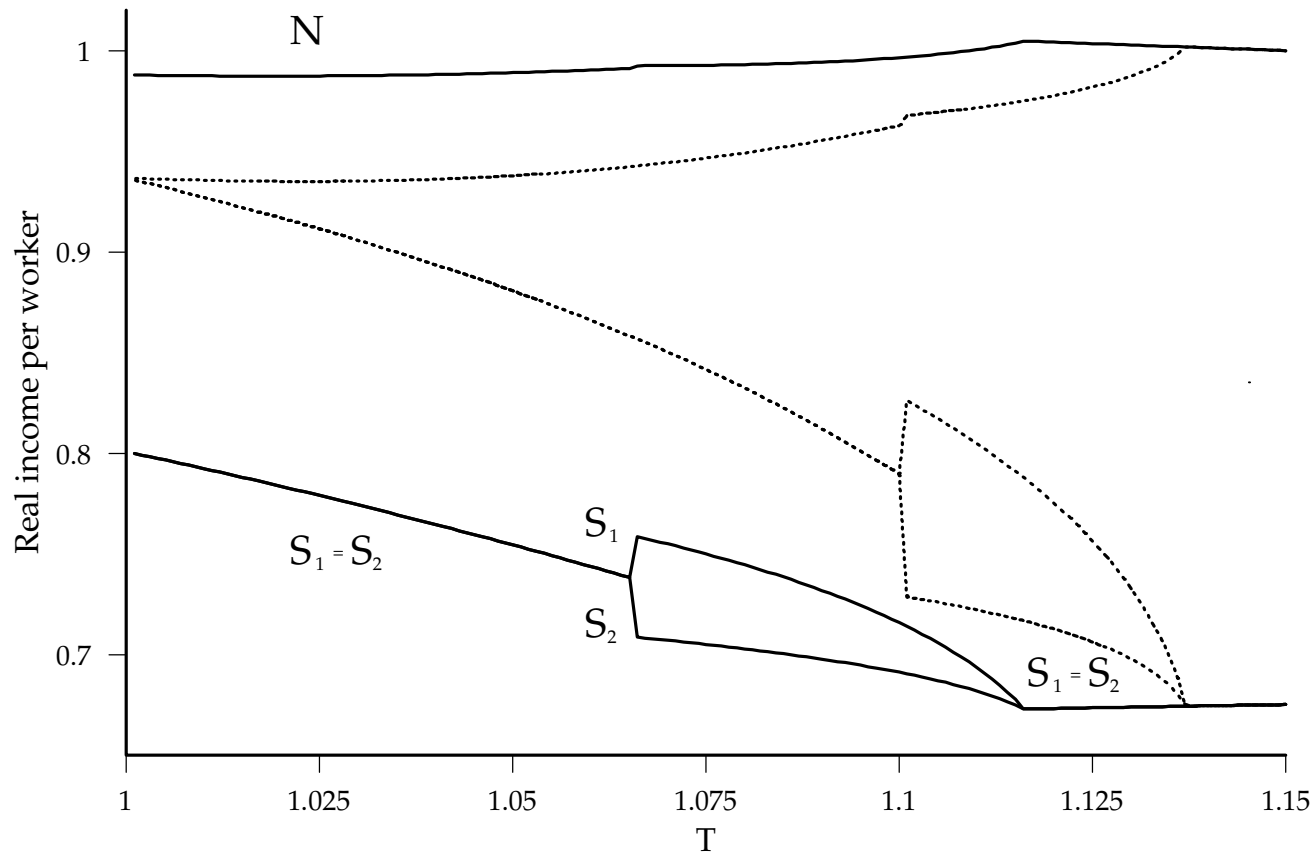

FIGURE $4 b$

Concerted MFN Southern liberalisation: Real income per worker 


\subsection{Concerted most-favoured-nation Southern liberalisation}

We now look at the effects of what the World Bank (1994) calls concerted mostfavoured-nation (MFN) liberalisation by both Southern economies. All Southern import tariffs are reduced, so only Northern tariffs remain. This amounts to a South-South PTA plus liberalisation of Southern imports from the Northern economy. Figures $4 a$ and $4 b$ illustrate the results.

The evolution of industry is similar to that of a South-South PTA. Industrialisation starts first in one Southern country, then in the other. The process of industrialisation starts sooner (at higher levels of $T$ ) in one of the countries than is the case with unilateral liberalisation; this is because the relationship with North is the same, and in addition there are the benefits of Southern liberalisation. Comparing this case with a South-South PTA we see in the example illustrated that there is earlier industrialisation. However, this is not general - liberalisation with North brings benefits from forward linkages and disadvantages from import competition, the net effect of which is ambiguous.

At low levels of tariffs concerted MFN Southern liberalisation gives a higher level of real income than unilateral liberalisation, but lower than both South-South PTA and multilateral liberalisation. This is because of the asymmetry in North-South trading arrangements. Southern exports to North still face a tariff barrier, while Northern imports to South are untaxed.

\subsection{North-South PTA}

What if, instead of liberalising bilaterally with the other Southern economy, one of the Southern countries forms a PTA with North ${ }^{[14]}$ Figures $5 a$ and $5 b$ summarise the results.

A North-South PTA spreads a larger share of industry to the liberalising Southern economy, and gives this economy higher real wages, than any of the other arrangements we have considered (compare it with the multilateral case given by the dashed lines). This is because a PTA with North gives a Southern economy the benefits

14 Recall that North is assumed to be a single policy making agent, so the PTA is with both Northern economies. 


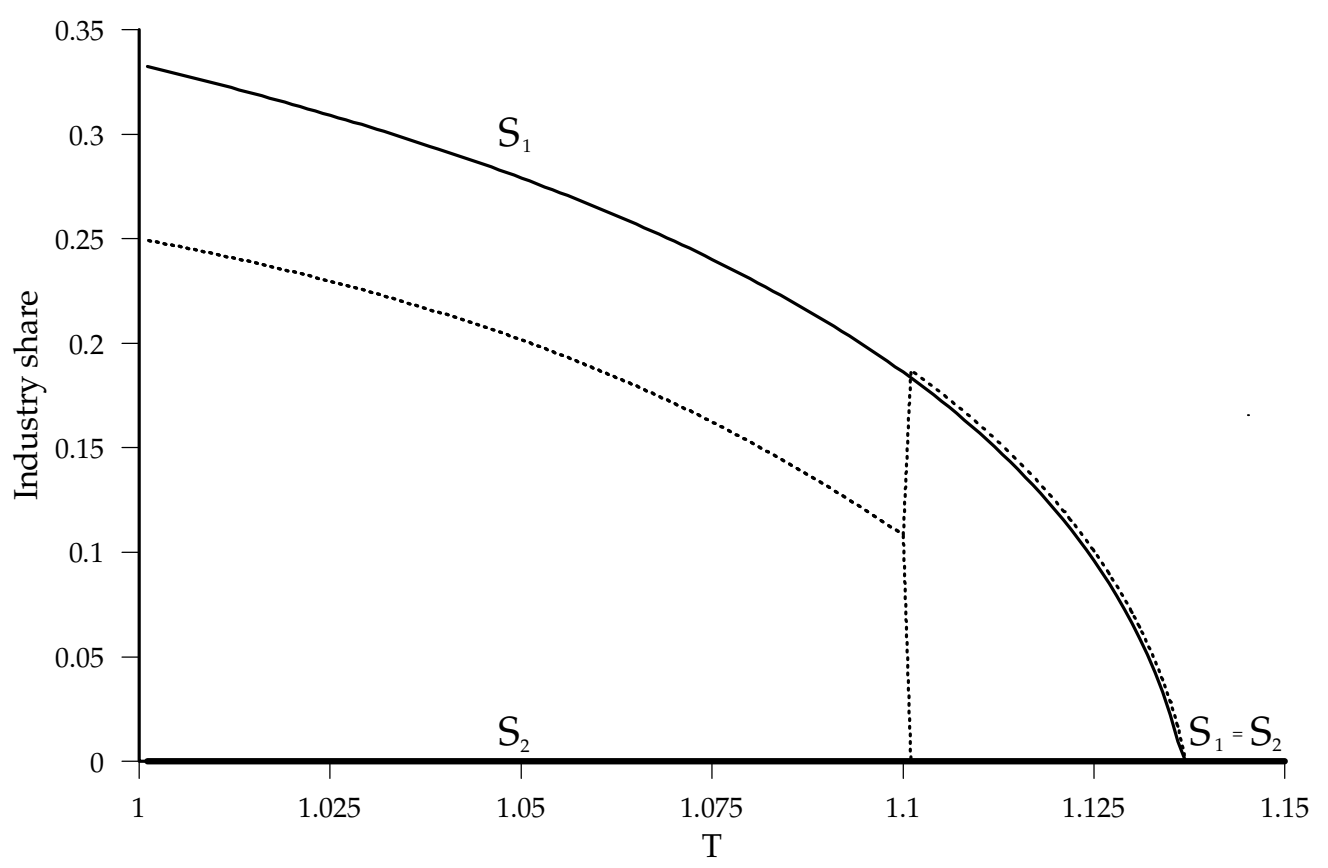

FIGURE 5a

North-South FTA: Share of industry in each country

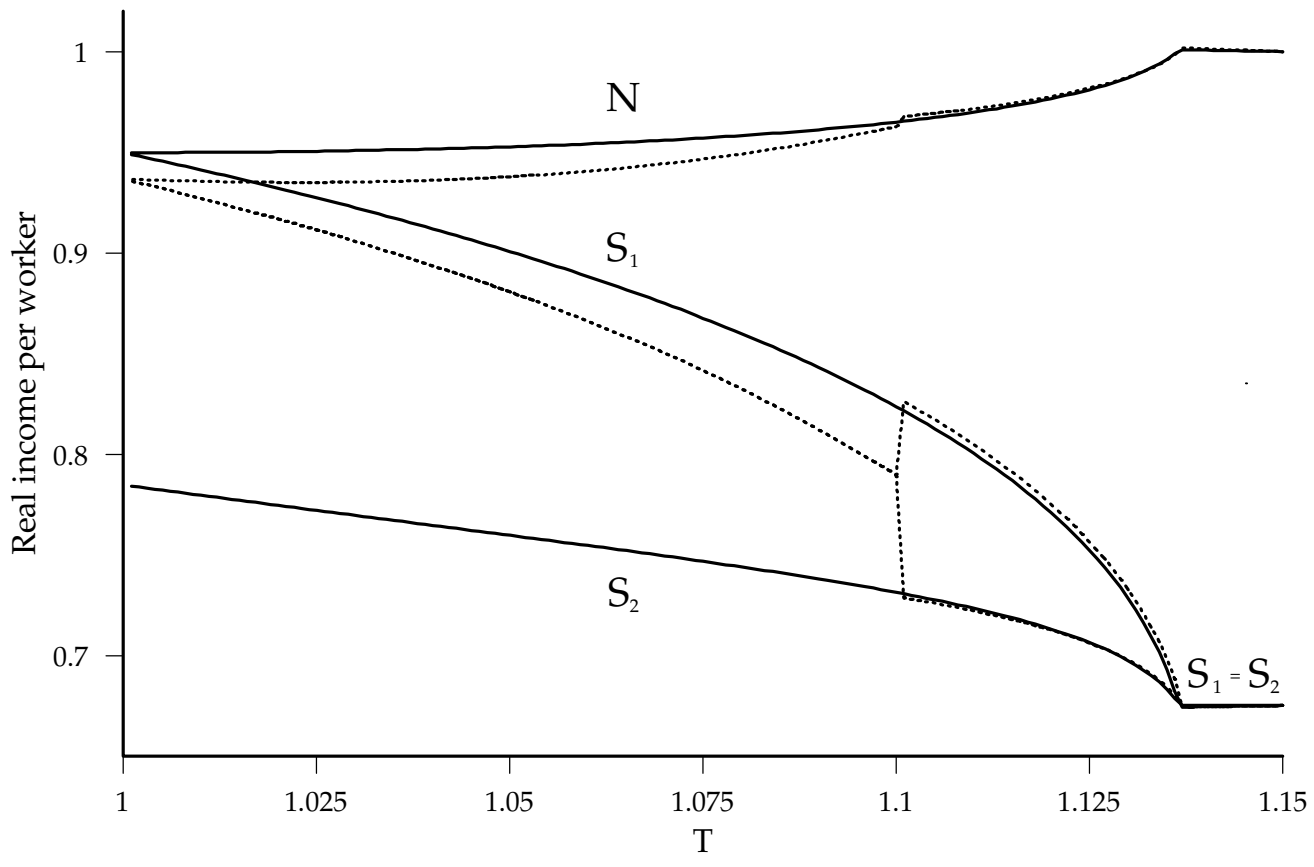

FIGURE 5b

North-South FTA: Real income per worker 
of both improved access to the large Northern market and low cost availability of Northern intermediates. The liberalising Southern economy suffers from more competition from Northern firms but, because Southern wages are lower, the balance of better reciprocal market access is in favour of South. This spread of industry is associated with a large fall in Northern's share of industry (and also a fall in Northern real wages). The loser (compared to other arrangements) is of course the other Southern economy which does not attract any industry and only experiences a slight increase in real wages through the rise in world industrial production.

\subsection{Hub-and-spoke}

The previous experiment assumed that North formed a PTA with just one Southern economy. An interesting alternative is that in which North forms a bilateral PTA with each of the Southern economies, but these keep barriers between them unchanged. This kind of trade policy arrangement turns North (that is, both Northern economies jointly) into the 'hub' of this hub-and-spoke arrangement.

Figures $6 a$ and $6 b$ represent such a case. It brings relatively rapid and strong industrialisation to South, for the same reasons that applied in the case of a bilateral North-South PTA. Both Southern economies are affected, although there is an initial phase of divergence between them. The spread of industry to South is however less

pronounced than under multilateral liberalisation because location in each of the Southern economies is penalised by the barriers between the Southern economies. It is this which enables North to maintain a higher real wage in this case than in either of the other two experiments involving Northern liberalisation.

\section{Policy issues}

How relevant in practice are the forces captured in this framework? How much evidence is there to support the argument that PTAs cause such changes in the production structure of nations? The only study of which we are aware that directly 


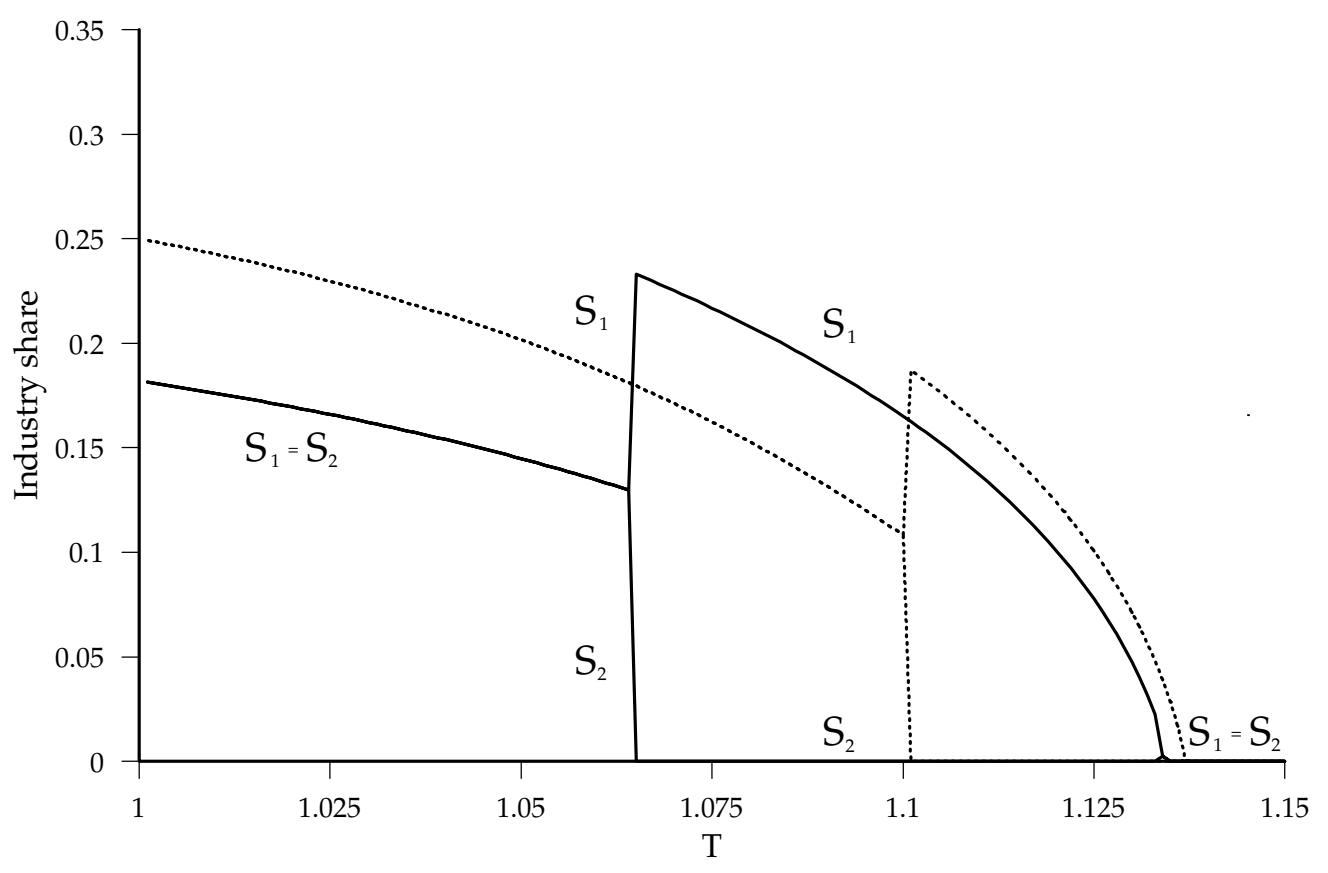

FIGURE 6a

Hub-and-spoke: Share of industry in each country

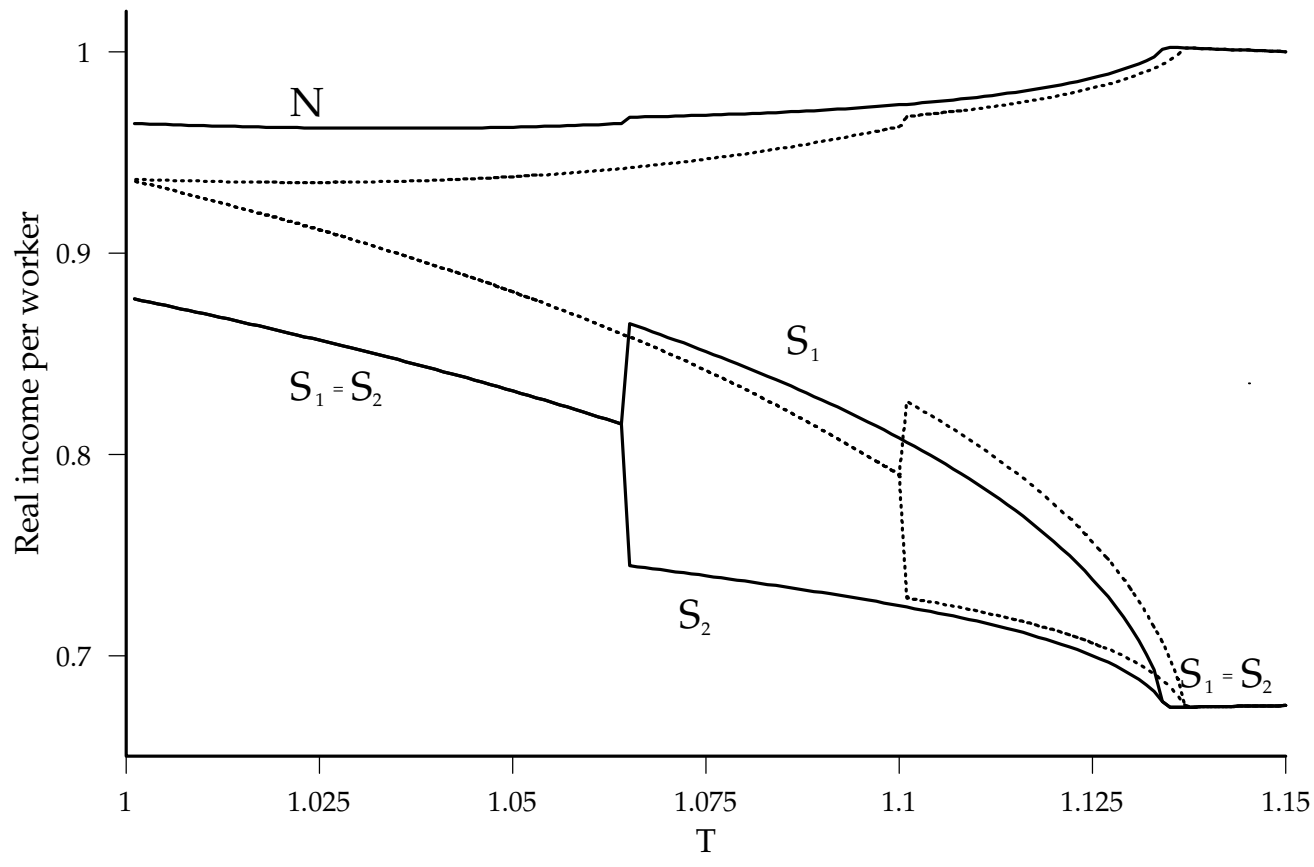

FIGURE 6b

Hub-and-spoke: Real income per worker 
addresses these issues is Hanson's work on Mexico. Hanson (1994), using data on Mexico, finds support for the hypothesis that agglomeration is associated with increasing returns. He also shows (Hanson, 1997) that integration with the Us has had strong effects on industry location in Mexico. Industry has shifted towards states with good access to the US market (demand linkages). At the same time, employment growth has been higher in regions that have larger agglomerations of industries with buyer/supplier relationships (cost linkages).

While there is support for the relevance of these forces, we are not aware of any empirical work on their importance under specific trading arrangements. Nevertheless we believe the experiments of the previous section can shed some light on some of the trade policy choices currently faced by LDCs. The remainder of this section discusses the main implications.

\subsection{Unilateral or concerted liberalisation?}

Recent years have seen many LDCs (in particular East Asian economies) undertake unilateral trade liberalisation. However, others (including some members of the AsiaPacific Economic Cooperation process, APEC) have been reluctant to lower their tariffs without receiving reciprocal concessions. What are the benefits of unilateral liberalisation, and can countries expect to do better by concerted action?

The answer to the first part of this is, as we have seen (3.2), that unilateral liberalisation can attract industry and bring a real income gain. Although more intense import competition has an adverse effect on profitability in the liberalising economy, import supply creates beneficial forward linkages to domestic production and promotes industrialisation. While in the model such linkages arise just from the use of these goods as inputs, in reality we might think of these linkages coming through several channels. As a recent World Bank (1994) study argues:

'By opening their economies, countries gain access to more affordable consumer goods and to technologies and intermediate goods that help reduce production costs. Thus, by improving the climate for investment, liberalisation also helps to attract foreign capital. Foreign investment, in turn, can provide the technology and financing required to establish a more efficient production structure.' 
Tybout and Westbrook (1994) find that trade liberalisation in Mexico has reduced average costs in most industries. In more export-oriented industries these cost reductions were due mainly to the type of forces captured by our model (falling prices of intermediates), while in sectors with higher import penetration these cost effects appeared to be combined with relative productivity improvements. At the same time they find that increased import penetration has shifted downwards the demand for domestic products.

In our analysis we find that the balance between import competition and cost linkages, combined with low initial wages, tends to work out in favour of the liberalising economy, leading to industrialisation, as in figure 2. However, the benefits of unilateral liberalisation alone, may be comparatively small; in our examples full unilateral liberalisation gave a lower real income than any of the other experiments considered. What can LDCs do to better promote industrialisation through trade policy?

Our analysis suggests the strong likelihood of gains from concerted action, but two reservations have to be made. The first is that the gains from concerted action may not be divided equally between the members. Even in the case of concerted MFN liberalisation there may be some range of tariffs in which one country does worse than it would if it were the only country to liberalise. We return to these issues of division of the gains in section 4.4. The second qualification is that, even though all our simulations give greater gains from concerted action than from unilateral, we have no general theorems - all results are sensitive to specification of the model and of the experiment. In particular, North-South and South-South PTAs operate in quite different ways, and we now turn to comparison of these two cases.

\subsection{South-South or North-South?}

Should countries with highly developed industrial systems be part of the concerted liberalisation, or excluded from it?

South-South PTAs work essentially by enlarging market size, and their success is dependent on the combined market size being large enough to attract industry. Analysis indicates that the smaller are the Southern countries then the later and less is 
the industrialisation (in terms of the figures we have presented, the curves $S_{1}$ and $S_{2}$ are pushed down and to the left). The mechanism is a form of trade diversion but - unlike the traditional analysis outlined in the introduction - the diversion may be successful in bringing about a 'critical mass' of activity from which a viable, and welfare improving, industrial base is created. Evidently, the market size of the group must reach a certain minimum size for this to work. The failure of many South-South PTAs can perhaps be attributed to inadequate scale. As Corden (1993) puts it:

'It is far better for Argentina to go for the world market - i.e., to liberalise unilaterally and in a non-discriminatory fashion, as she has been doing - than just go for the Brazilian market. Brazil has the largest economy in the Third World, and yet it is smaller than Canada's (as measured by the dollar value of GDP). And this applies even more to Brazil.'

North-South PTAs work quite differently, on the basis of improved access to the large Northern market and improved supply of intermediate goods, offset by increased import competition in domestic markets. In all cases we have examined North-South arrangements are, from the point of view of the participating Southern economies, better than South-South agreements. The reasons for the success of these North-South agreements merits some thought. In many new trade models the argument is made that liberalisation between economies of different sizes will draw industry into the country with the large market (the 'centre') and away from smaller ('peripheral') countries. However, the strength of these forces is greatest at intermediate levels of trade barrier, and at very low barriers factor price differences can overturn these effects. How does this relate to our findings that liberalisation will move industry out of the large economy to the small? Centripetal forces are certainly present in the model we have developed - indeed, they are amplified by forward and backward linkages. But these forces are precisely those that make for the North-South divide in the initial equilibrium - they create the initial wage differentials. Given this initial position and these wage differences, further liberalisation then moves industry out of the large and developed region, to the less developed. The circumstances that are most conducive to South benefiting from a North-South agreement of this type are, therefore, low remaining barriers to the Northern market (secured, for example, by proximity, as in NAFTA or the 
European Union's Southern regions and prospective Eastern regions), combined with low unit labour costs.

What about North? The flip side of Southern gains is that, in this framework, North may lose. As the industrial agglomeration in the Northern economy breaks down, so there may be a decline in Northern real income. These losses are greatest for SouthSouth liberalisation. Of the arrangements where North reduces barriers to Southern imports, multilateral liberalisation causes larger losses than hub-and-spoke arrangements. This may be one of the reasons that has induced the European Union to choose a bilateral rather than multilateral approach to trade liberalisation with its neighbours. The set of bilateral association agreements that the European Union has established both in Central and Eastern Europe and in the Mediterranean have in effect turned it into the hub of a large web of trading arrangements.

Does this imply that North would be better off by not reducing its barriers to Southern imports? Not necessarily. In fact, our analysis suggests three reasons why not liberalising may be a worse option.

First, Northern losses in this context are not general. All our experiments start from an equilibrium in which South has no industry, so Northern has no manufacturing imports and there are large differences in unit labour costs. With higher initial development levels in South and smaller initial differences in unit labour costs, real wages in North tend to rise instead (see Krugman and Venables, 1995, for an elaboration of this point). ${ }^{[15]}$

Second, even if North were to lose from opening its market to Southern imports, it would lose more from remaining closed while Southern economies liberalise amongst themselves. Comparison of South-South vs. multilateral liberalisation shows that in either case industry spreads to Southern countries, but under South-South liberalisation Northern firms and consumers have to pay higher prices on the increasing number of goods produced in South, so real wages are lower.

${ }^{15}$ Recall also that we have excluded any gains from trade through comparative advantage, which in practice are likely to bring further benefits to Northern consumers. 
Third, falling real wage differences between North and South may help reduce migration pressures. One of the main arguments in favour of NAFTA in the United States was reducing illegal migration from Mexico (and, in fact, Hanson and Spilimbergo, 1996, show that illegal migration from Mexico to the US is very responsive to changes in relative wages).

\subsection{Non-discriminatory liberalisation vs. Southern trading blocs}

The APEC process has raised hopes that integration in the Asia-Pacific region may develop in a less inward-looking way than in other geographical areas, and perhaps even catalyse deeper global trade liberalisation. Calls for the formation of a regional trading bloc in Asia have received little support. The amount of trade covered by ASEAN, the Association of Southeast Asian Nations, remains small. The East Asian Economic Group (EAEG) has so far lacked the necessary backing to take off. Instead, inward-looking regional integration is giving way to APEC's vision of 'open regionalism'.

In the report presented at APEC's 1994 annual summit in Bogor, the APEC Eminent Persons Group explained APEC's vision of open regionalism as follows. First, APEC members should liberalise intra-APEC trade flows on a non-discriminatory basis. Second, APEC should, as a group, treat nonmembers as it does members, provided that nonmembers make reciprocal offers. Third, any individual APEC member should have the choice to unilaterally waive such reciprocity requirement and extend its APEC liberalisation to all nonmembers.

APEC's members have so far been divided over this last point. While East Asian countries have favoured openness towards non-members, the US President, Bill Clinton, made clear before APEC's Bogor summit that any trade concessions would be reciprocal, and that there would be 'no free-riders'. One year later at the Osaka summit Australia's trade minister, Bob McMullan, stressed that they would also give 'nothing for nothing'.

Outside Asia other countries have also seen the need to reciprocally open their markets. The main argument was highlighted by the Economist (29 June 1996) after Chile signed its FTA with Mercosur: '[d] espite continued protectionist pressure from 
their weaker industries, Mercosur's leaders all know that, to attract investment they need to compete in the wider world, their firms want a bigger home market.' However, in the case of Mercosur unilateral liberalisation is not even on the agenda. Instead its member countries are advancing towards a regional FTA that will liberalise trade flows between members but not imports from outsiders. What can we say on the basis of our analysis on the comparison between concerted MFN liberalisation and a South-South FTA?

We have already discussed the trade-off. Non-discriminatory liberalisation brings beneficial cost linkages, but also more intense competition from outsiders. Comparison of figures 3 and 4 show that the former effect is most important in the early stages of industrialisation, and the latter in determining real income once industry is established. Concerted MFN liberalisation brings earlier industrialisation than South-South, but at very low tariff levels South-South leads to more Southern industry. These results are quite sensitive to parameter values. In particular, if Southern economies are small concerted MFN works better for them. This is because with a small home market most of their sales will take place abroad, so protective tariffs are of little help to them, but extending liberalisation unilaterally to non-members lowers the cost of intermediates and helps industrialisation take off. Given this, it is not surprising what we have observed in Asia: smaller countries pushing for unilateral liberalisation while larger ones insist on reciprocal concessions. ${ }^{[16]}$

\subsection{Southern disparities}

In all the cases in which the two Southern economies follow symmetric policies we have seen that the outcome is, for some interval of tariffs, asymmetric, with only one of the Southern countries having industry. In the theoretical model the two Southern countries are assumed to be identical, so there is no basis for deciding which country has industry

16 The fact that more small than large countries have liberalised unilaterally can also be explained by smaller countries having less bargaining power to extract reciprocal concessions. What is striking is that smaller Asian countries not only tend to have more open regimes, but have also generally expressed their preference for a more open approach to trade liberalisation even if larger countries in APEC were not to do the same. 
- it is simply a matter of chance. In practice, differences between the two countries will decide the issue (possibly quite small differences). The mix of factors obviously includes institutional, political, and geographical considerations. To highlight a few, geographical proximity to the existing industrial centre will be beneficial, in so far as closeness is associated with lower natural trade barriers. (This, we think, provides an interesting way of thinking about the spread of industry from Japan through the newly industrialising economies). Low unit labour costs and a larger home market will also pull in this direction - unsurprisingly, cheaper efficiency units of labour and a larger home market, other things being equal, increases the attraction of a country as a base for industry.

These differences may however be dominated by the policy regime of the government, and this creates scope for policy action to obtain a 'first mover advantage' and attract industry before it becomes established elsewhere. In the trade policy context this creates the following incentives.

First, LDCs will have an incentive to establish trade links with developed countries. As we have seen, North-South FTAs may be effective in attracting industry to South. More generally, links with developed countries may give a particular LDC the margin that is needed to ensure that it becomes the first to industrialise in a South-South trading arrangement.

The second trade policy incentive arises in a multi-country setting. Countries which are late entrants to an FTA will certainly not be the ones that first attract industry, so there is an incentive to be amongst the founding group.

Third, a reduction of barriers within an FTA can have a 'domino' effect: it creates incentives for more countries to join the agreement. ${ }^{[17]}$ This can be seen in figure 5 . If $S_{1}$ forms a PTA with North which lowers gradually tariffs on intra-PTA trade, once tariffs

17 Baldwin (1993) models a different - but related - mechanism driving the domino pattern of PTA membership. In his model, there is a fixed number of firms in each country with a variable equilibrium scale of operation. Integration within the PTA increases the gains from membership for firms in excluded nations, leading them to exercise stronger pressure in favour of membership. The sequence of entry is driven by countries' idiosyncratic opposition to membership. In our model, integration within the PTA makes location in the next country to join profitable. Entry eliminates profits, fully passing on to consumers the benefits of membership. Sequential entry arises with homogenous countries: once a country joins a PTA it pays the next country to wait until barriers within the PTA are reduced further. 
fall below $T=1.1 S_{2}$ 's real income would be higher if it also joined the agreement as this would allow it to attract industry.

In addition to creating incentives for countries to attract industry, the possibility that industry will agglomerate in a subset of member countries may also create real tensions within the PTA. The history of Southern PTAs is littered with schemes that have failed, often because of internal disputes over the location of industry and the design of compensation schemes for perceived losers in the arrangement (a typical example is the Treaty of Brazzaville, which was intended to create a customs union and a common currency area with the former French Central African countries - see Foroutan, 1993, who shows that the distortionary nature of compensations undid any benefits from the PTA).

One message from this paper is that the differences between countries may only be transitional - in our figures the differences disappear as tariffs are reduced low enough. However, there is no guarantee that the final liberalisation will necessarily go far enough to iron out differences and secure the spread of industry to all participating Southern economies, particularly if there are substantial underlying differences between these economies.

\section{Conclusions}

In this paper we have outlined a new approach for analysing the role of trade in promoting industrial development. Interactions between imperfect competition, trade costs, and an input-output structure create incentives for firms to locate close to supplier and customer firms. Clustering of firms then occurs, so that even if countries are identical in underlying structure, only a few countries are industrialised. These countries have high wages, but the positive pecuniary externalities created by inter-firm linkages compensate for the higher wage costs. Trade liberalisation changes the attractiveness of countries as a base for manufacturing production, and can trigger or postpone - industrial development. 
The process we describe abstract from many important aspects of reality. We have no capital accumulation (physical or human), and no interregional or international differences in technology or endowments. We have only a single policy instrument - a tariff that is unable to discriminate between different types of industrial imports. There is no explicit modelling of the political process that leads to a particular choice of policy, nor of policy games between governments. Even within its framework the model we employ is simple. For example, firms are modelled as single plant operations, so multinationality and foreign direct investment are not considered. Also, firms are footloose and atomistic, which is helpful for focussing on long-run outcomes but abstracts from the costs of relocation and from strategic interaction. All these points create possible directions for future research, but, even at our level of abstraction, we think the model captures a number of features of the world economy which seem to be important, and provides some new insights on the effects of trading arrangements on industrial development.

It offers an explanation as to why firms are reluctant to move to economies that have lower wages and labour costs, and shows how trade liberalisation can change the incentives to become established in developing countries. It provides a mechanism through which import liberalisation can have a powerful effect in promoting industrialisation. And it suggests that import liberalisation may create or amplify differences between liberalising countries with the possible political tensions this may create. While these features are consistent with the world economy, they of course fall far short of providing convincing empirical support for the approach.

Using the approach we derive a number of conclusions about the effects of trade liberalisation. The first is that unilaterally liberalising imports of manufactures can promote development of local manufacturing industry. The mechanism is forward linkages from imported intermediates, but this may be interpreted as part of a wider package of linkages coming from these imports. Second, the gains from liberalisation through PTA membership are likely to exceed those that can be obtained from unilateral action. South-South PTAs will be sensitive to the market size of member states, and North-South PTAs seem to offer better prospects - for participating Southern economies, if not for North and excluded countries. Third, the effects of particular schemes (on, for 
example, the division of benefits between Southern economies) will depend on the characteristics of the countries, and cross-country differences in these characteristics. We have not yet conducted systematic investigation of the sensitivity of our results to such differences.

\section{Appendix}

We consider a world with 4 regions, two Northern and two Southern, $N_{1}, N_{2}, S_{1}$ and $S_{2}$. Each region is endowed with $L$ workers and $K$ units of arable land, and can produce agricultural and industrial output. Both primary factors are immobile between regions. Arable land is used only by the agricultural sector, while labour is used both by agriculture and by industry, and is perfectly mobile between sectors.

\section{Agriculture}

Agriculture is perfectly competitive. It produces under constant returns to scale a homogenous output, which we assume costlessly tradeable and choose as numéraire. In each region the agricultural production function is Cobb-Douglas in land and labour, with labour share $\theta$. If $L_{i}^{A}$ denotes agricultural employment, agricultural output is $\left(L_{i}^{A}\right)^{\theta} K_{i}^{(1-\theta)}$, and the local wage is

$$
w_{i}=\theta\left(L_{i}^{A}\right)^{(\theta-1)} K_{i}^{(1-\theta)}
$$

\section{Industry}

The industrial sector has imperfectly competitive firms, producing differentiated goods under increasing returns to scale. Production of a quantity $x_{i}(k)$ of any variety $k$ in any country $i$ requires the same fixed $(\alpha)$ and variable $\left(\beta x_{i}(k)\right)$ quantities of the production input. That production input is a Cobb-Douglas composite of labour and a constant 
elasticity of substitution (CES) aggregate of the differentiated industrial goods. The cost function of a firm producing variety $k$ in country $i$ is

$$
C_{i}(k)=q_{i}^{\mu} w_{i}^{(1-\mu)}\left(\alpha+\beta x_{i}(k)\right)
$$

where $q_{i}$ is the price index of the aggregate, defined by

$$
q_{i} \equiv\left[\sum_{j=1}^{4} \int_{h \in N_{j}}\left(p_{j, i}(h)\left(T_{j, i} \tau\right)\right)^{(1-\sigma)} \mathrm{d} h\right]^{1 /(1-\sigma)} .
$$

The price index in each country depends on the local prices of individual varieties, which in turn are a function of the free on board (FOB) prices, real trade costs, and tariffs. The elasticity of substitution between varieties, $\sigma(>1)$, is assumed to be the same in all countries. $N_{j}$ is the set of varieties produced in location $j$, and $p_{j, i}(h)$ is the FOB price of variety $h$ shipped from country $j$ to country $i$. Real trade costs for the industrial goods take Samuelson's 'iceberg' form: $\tau$ units have to be shipped so that one unit arrives in another region. Industrial goods exported from $j$ to $i$ are also subject to an ad valorem tariff $T_{j, i}-1$.

\section{Preferences}

Turning to the demand side, consumers have Cobb-Douglas preferences over the agricultural good and a CES aggregate of industrial goods. All industrial varieties produced enter consumers' utility function with the same constant elasticity of substitution with which they enter firms' technology. The indirect utility function of a worker in region $i$ is then given by

$$
V_{i}=q_{i}^{-\gamma} 1^{-(1-\gamma)} w_{i}
$$

Landowners have the same preferences as workers, but are assumed to be tied to their land. 


\section{General equilibrium}

Expenditure on manufactures in each region can be derived from (2), (3) and (4) as

$$
e_{i}=\gamma\left[w_{i} L_{i}+(1-\theta)\left(L_{i}^{A}\right)^{\theta} K_{i}^{(1-\theta)}+\int_{h \in N_{i}} \pi_{i}(h) \mathrm{d} h+R_{i}\right]+\mu \int_{h \in N_{i}} C_{i}(h) \mathrm{d} h
$$

The first term is the value of consumer expenditure (including tariff revenue, denoted by $\left.R_{i}\right)$, and the second the value of intermediate demand, since consumers spend a fraction $\gamma$ of their income and firms a fraction $\mu$ of their costs on manufactures.

The division of consumers' and producers' expenditure on each industry between individual varieties of industrial goods can be found by differentiation of the price index with respect to the price of the variety. Total demand for a single variety produced in $i, x_{i}$, is

$$
x_{i}(k)=\tau^{(1-\sigma)} \sum_{j=1}^{4}\left(p_{i, j}(k) T_{i, j}\right)^{-\sigma} q_{j}^{(\sigma-1)} e_{j} .
$$

Since the producer of an individual good faces an elasticity of demand $\sigma$, firms mark up price over marginal cost by the factor $\sigma /(\sigma-1)$ :

$$
p_{i}=\frac{\sigma \beta}{\sigma-1} q_{i}^{\mu} w_{i}^{(1-\mu)}
$$

The value of tariff revenue is

$$
R_{i}=\sum_{j=1}^{4}\left(T_{j, i}-1\right) n_{j} p_{j} x_{j} .
$$

The profits of an individual manufacturing firm are, from expressions (2) and (7),

$$
\pi_{i}=\frac{p_{i}}{\sigma}\left(x_{i}-x\right)
$$


where

$$
x=\frac{\alpha(\sigma-1)}{\beta}
$$

is the unique level of output giving firms zero profits. As usual in this type of model, equilibrium firm scale is a constant, depending only on demand and cost parameters.

Turning to the labour market, we can write the labour market clearing condition as

$$
L_{i}=(1-\mu) n_{i} \frac{C_{i}}{w_{i}}-L_{i}{ }^{A},
$$

where $n_{i} \equiv \# N_{i}$ denotes the mass of firms in region $i$ (to which we refer as the number of firms in region $i$ ). The first term on the right hand side of (12) is labour demand in manufacturing, obtained by application of Shephard's lemma to (2), and the second term is labour demand in agriculture.

This completes the description of short run equilibrium. At any instant we think of the economy as having a predetermined number of firms in each region. To this corresponds a short-run equilibrium defined as a set of wages and price indices solving the following eight equations. The first four equations are the price indices of manufactures in each of the four regions, obtained by substitution of (7) into (3). The other four equations come from substituting (1), (2), and (5)-(10) into (11), which gives the labour market clearing condition in each region. We can then express profits at the short-run equilibrium in terms of the number of firms by substituting equations (1)-(2), (5)-(8), and (10), and the short-run equilibrium values of wages and price indices into (9).

A long-run equilibrium obtains when the numbers of firms are such that there are zero profits in each country where there is a positive number of firms and negative profits (for potential, if not for actual, firms) wherever the number of firms is zero:

$$
\pi_{i} n_{i}=0, \pi_{i} \leq 0, n_{i} \geq 0,
$$

We assume a myopic entry and exit process, according to which firms enter and exit in response to profit opportunities. This is described by differential equations, 


$$
\dot{n}_{i}=\delta \pi_{i^{\prime}} \quad n_{i} \geq 0
$$

where $\delta(>0)$ is the speed of adjustment.

The system of equations (12) may support multiple equilibria, and under the dynamics of (13) some are stable and others unstable. Complete analysis of the structure of equilibria and of the dependence of bifurcation points of the system is undertaken for the case of symmetric changes in trade barriers in Puga (1996) and Fujita, Krugman and Venables (1997), and for asymmetric changes in trade barriers by Puga and Venables (forthcoming).

Our approach in this paper is to select the initial equilibrium in which two of the four economies have industry. For each experiment we take a small reduction in tariffs, and then let the model adjust according to the dynamics given by (13). Repeating this for successively lower tariffs traces out a path of stable equilibria, and gives the relationship between tariffs and endogenous variables illustrated in the figures.

Computation was undertaken using GAUSS code written by the authors, and this is available on request.

\section{Parameters and experiments}

Values of parameters are $\gamma=0.5, \theta=0.8, \mu=0.55$, and $\sigma=4$. At the starting point in all our experiments there are real trade costs of $\tau=1.1$ between all four regions, an ad valorem tariff of $15 \%(\bar{T}=1.15)$ for all North-South and South-South trade, and free trade between the two Northern economies $(T=1)$. These values are such that at the initial level of tariff barriers there is a stable equilibrium in which all industry is split between the two Northern economies (qualitatively the same initial equilibrium can be supported by for a range of values of either type of barrier).

The experiments look at the evolution of this equilibrium as some (or, in the case of multilateral liberalisation, all) of these tariffs are brought down to zero $(T=1)$, with those not affected by the liberalisation held at $\bar{T}$. Real barriers are kept unchanged (reductions in real barriers instead of reductions in tariffs have very similar effects to those presented although there is no revenue foregone). 


\section{References}

Asia-Pacific Economic Cooperation, Eminent Persons' Group. 1994. Achieving the APEC Vision: Free and Open Trade in the Asia-Pacific.

Baldwin, Richard E. 1993. 'A domino theory of regionalism.' Working Paper No. 4465, National Bureau of Economic Research.

Baldwin, Richard E. 1994. Towards an Integrated Europe. London: Centre for Economic Policy Research.

Baldwin, Richard E. and Anthony J. Venables. 1995. 'Regional economic integration.' In Gene M. Grossman and Kenneth Rogoff (eds.). Handbook of International Economics, 3, Amsterdam: North-Holland: 1597-1644.

Corden, W. Max. 1993. 'Round Table Discussion.' In Jaime de Melo and Arvind Panagariya. New Dimensions in Regional Integration. Cambridge: Cambridge University Press.

De Melo, Jaime, Arvind Panagariya and Dani Rodrik, 1993. 'The new regionalism: acountry perspective.' In Jaime de Melo and Arvind Panagariya. New Dimensions in Regional Integration. Cambridge: Cambridge University Press.

Dixit, Avinash K. and Joseph E. Stiglitz. 1977. 'Monopolistic competition and optimum product diversity.' American Economic Review, 67: 297-308.

Economist. 29 June 1994. 'Getting together: South America. Mercosur gets bigger and stronger.'

Fujita, M., P. Krugman and A.J. Venables, 1997, The Spatial Economy: Cities, Regions and International Trade. Manuscript, London School of Economics.

Foroutan, Faezeh. 1993. 'Regional integration in Sub-Saharan Africa: past experience and future prospects.' In Jaime de Melo and Arvind Panagariya. New Dimensions in Regional Integration. Cambridge: Cambridge University Press.

Hanson, Gordon H. 1994. 'Regional adjustment to trade liberalisation.' Working Paper No. 4713, National Bureau of Economic Research.

Hanson, Gordon H., 1997 'Increasing returns, trade, and the regional structure of wages.' Economic Journal, 107: 113-133.

Hanson, Gordon H. and Antonio Spilimbergo. 1996. 'Illegal immigration, border enforcement, and relative wages: Evidence from apprehensions at the US-Mexico border.' Working Paper No. 5592, National Bureau of Economic Research.

Helpman, Elhanan and Paul R. Krugman. 1985. Market Structure and Foreign Trade. Cambridge, MA: MIT Press. 
Krugman, Paul R. 1980 'Scale economies, product differentiation, and the pattern of trade.' American Economic Review, 70: 950-959.

Krugman, Paul R. and Anthony J. Venables. 1995. 'lobalization and the inequality of nations.' Quarterly Journal of Economics, 110: 857-880.

Pande, Rohini. 1997. 'Transforming economies: Agricultural mechanisation and the process of industrialisation.' Manuscript, London School of Economics.

Puga, Diego and Anthony J. Venables. Forthcoming . 'Preferential trading arrangements and industrial location.' Journal of International Economics.

Puga, Diego and Anthony J. Venables. 1996. 'The spread of industry: spatial agglomeration in economic development.' Journal of the Japanese and International Economies, 10: 440-464.

Tybout, James R. and M. Daniel Westbrook. 1994. 'Trade liberalization and the dimensions of efficiency change in Mexican manufacturing industries.' Journal of International Economics, 39: 53-78.

Venables, Anthony J. 1996. 'Trade policy, cumulative causation, and industrial development.' Journal of Development Economics, 49: 179-198.

World Bank. 1994. East Asia's Trade and Investment: Regional and Global Gains from Liberalization. Washington, DC: World Bank. 